\title{
低用量アスピリン及び非ステロイド性消炎鎮痛薬による消化管障害の危険性の評価
}

\author{
矢口武廣, ${ }^{a}$ 横山晴子, ${ }^{a}$ 中村浩規, ${ }^{a}$ 鈴木優司, ${ }^{b}$ \\ 徳岡健太郎, ${ }^{c}$ 渡邊昌之, ${ }^{b}$ 北川泰久, ${ }^{c}$ 山田安彦 $*, a$
}

\section{Evaluation of the Development of Gastroduodenal Lesions in Patients Treated with Low-dose Aspirin or Non-steroidal Anti-inflammatory Drugs}

\author{
Takehiro YAGUCHI, ${ }^{a}$ Haruko YoKOYAMA, ${ }^{a}$ Hironori NAKAMURA, ${ }^{a}$ Yuji SUZUKI, ${ }^{b}$ \\ Kentaro TOKUOKA, ${ }^{c}$ Masayuki WATANABE, ${ }^{b}$ Yasuhisa KITAGAWA, ${ }^{c}$ and Yasuhiko YAMADA ${ }^{*, a}$ \\ ${ }^{a}$ Department of Clinical Evaluation of Drug Efficacy, School of Pharmacy, Tokyo University \\ of Pharmacy and Life Sciences, 1432-1 Horinouchi, Hachioji, Tokyo 192-0392, Japan, \\ ${ }^{b}$ Department of Pharmacy, and cDepartment of Neurology, Tokai University \\ Hachioji Hospital, 1838 Ishikawa-cho, Hachioji, Tokyo 192-0032, Japan
}

(Received October 4, 2010; Accepted April 1, 2011; Published online April 7, 2011)

\begin{abstract}
Aspirin irreversibly inhibits the enzyme cyclooxygenase- 1 and depresses the production of thromboxane $\mathrm{A}_{2}$, and also exerts antiplatelet effects. On the other hand, it also depresses the production of prostaglandin $\mathrm{E}_{2}\left(\mathrm{PGE}_{2}\right)$ and induces gastroduodenal lesions, which are often seen in patients taking aspirin. The aim of this study was to clarify the degree of gastroduodenal lesions induced by low-dose aspirin. We investigated the incidence rate of such lesions induced by aspirin and non-steroidal anti-inflammatory drugs (NSAIDs), and performed theoretical evaluations in a retrospective study. The incidence rates of gastroduodenal lesions in the low-dose aspirin $(n=1103)$ and NSAIDs $(n=1856)$ groups were $2.54 \%$ and $0.27 \%$, respectively, which was significantly greater in the aspirin group. Furthermore, the calculated value of inhibition rate of gastric $\mathrm{PGE}_{2}$ was significantly correlated with the actual value after administration of aspirin or NSAIDs $(r=0.902, p<0.05)$, which suggested that the calculated value reflected the actual value. The calculated value of aspirin (98.9\%) was higher than that of NSAIDs (3.67-70.8\%) after administration of the drugs with the standard doses. Our findings indicate that the incidence rate of gastroduodenal lesions induced by low-dose aspirin was higher than that of those induced by NSAIDs. Therefore, we were able to perform a theoretical evaluation of the occurrence of gastroduodenal lesions.
\end{abstract}

Key words_ aspirin; non-steroidal anti-inflammatory drug; gastrodudenal lesion; prostaglandin $\mathrm{E}_{2}$; cyclooxygenase-1

緒言

アスピリンは抗血小板作用を有し，血栓性疾患に おいて血栓形成の再発予防に低用量で用いられてい る。その一方で，低用量にもかかわらず副作用とし て消化管障害が臨床上重要な問題となっている. ${ }^{1)}$ アスピリンは血小板のシクロオキシゲナーゼ (COX) -1 を非可逆的に阻害することにより，血小 板凝集に関与するトロンボキサン（TX） $\mathrm{A}_{2}$ の産生 を阻害し，抗血小板作用を示す。一方，アスピリン は消化管粘膜に存在する COX-1 も阻害し，消化管 粘膜防御因子であるプロスタグランジン $(\mathrm{PG}) \mathrm{E}_{2}$

$a$ 東京薬科大学薬学部臨床薬効解析学教室, $b$ 東海大学 医学部付属八王子病院薬剂科, $c$ 同神経内科

*e-mail: yamada@ps.toyaku.ac.jp
の産生を抑制し，消化管障害を誘発する. ${ }^{2)}$

COX は, アラキドン酸に作用し $\mathrm{PGG}_{2}$ を経て $\mathrm{PGH}_{2}$ に変換する酵素であり, $\mathrm{COX}-1$ 及び COX-2 に分類される.COX-1 は様々な組織において発現 しており，血小板や胃などに恒常的に存在する。3) 一方，COX-2 は一般的に炎症などの刺激によって 誘導される. ${ }^{3)}$

アスピリンによる潰瘍やびらんなどの消化管障害 は，痛み等の自覚症状を伴わず，吐血や便潜血によ って発見されることが多く, 4,5$)$ その上，アスピリン は抗血小板作用を有しているため, 消化管出血を止 血し難く重症化する例も少なくない。低用量アスピ リンによる消化管障害に関しては，発現頻度等の報 告はあるものの, ${ }^{4,6}$ その危険性の程度は定量的に評 価されていない. 
そこで本研究では，まず，低用量アスピリンによ る消化管障害の危険性を明らかにするために， NSAIDs を対照薬剤として消化管障害の発現頻度に ついて遡及的調査を行い，比較検討した。ついで, 低用量アスピリンと NSAIDs による消化管障害の 発現頻度の相違に関する理論的な要因の解明を目的 として，アスピリン及び NSAIDs 服用後の胃切片 の $\mathrm{PGE}_{2}$ 産生阻害率の実測值と, 各薬物の胃におけ る $\mathrm{PGE}_{2}$ 産生に対する $\mathrm{IC}_{50}$ 值及び血漿中非結合型 薬物濃度 $\left(\mathrm{C}_{\mathrm{p}}^{\mathrm{f}}\right)$ から求めた見かけの胃 $\mathrm{PGE}_{2}$ 産生 阻害率との関係について検討した。そして，得られ た関係を基に，アスピリン及び NSAIDs による消 化管障害の危険性を理論的に解析した.

\section{方法}

\section{1. 低用量アスピリンと NSAIDsによる消化管 障害の発現頻度の比較}

1-1. 対象患者対象は東海大学医学部付属八 王子病院（以下，東海大八王子病院）にて，2006 年 1 月 1 日から 2008 年 12 月 31 日までの 3 年間 に，入院及び外来にて低用量アスピリン製剤又は NSAIDs 製剤が 30 日間以上処方された患者とし た。なお，対象調査期間の 2006 年 1 月 1 日より以 前から対象薬剤が継続服用されていた場合は，その 期間も含めた。本研究は遡及的調査であるため，上 部消化管内視鏡検查は，胃・十二指腸に疼痛などの 自覚症状を訴えた患者に施行され，胃炎，胃潰瘍， 十二指腸炎及び十二指腸潰瘍が認められた患者を消 化管障害発現患者とした。なお，低用量アスピリン と NSAIDsを併用していた患者，NSAIDsを 2 剂 以上服用していた患者，副腎皮質ステロイド製剤を 服用していた患者，ヘリコバクターピロリ陽性又は 感染歴がある患者は除外した。また，ヒスタミン $\mathrm{H}_{2}$ 受容体拮抗薬及びプロトンポンプ阻害薬を服用 していた患者も除外した。ただし，胃粘膜保護剤に ついては，ミソプロストールは除外対象としたが, 他の胃粘膜保護剤については低用量アスピリンによ る消化管障害に対する予防効果のエビデンスが十分 でないため, 7) 今回の調査では除外しなかった。

本研究は, 東京薬科大学薬学部倫理委員会及び東 海大学医学部付属病院群臨床研究審査委員会の承認 を取得後，行った．また，本研究はカルテ等の既存 資料による遡及的な観察研究であるため，疫学研究
に関する倫理指針に則り，東海大八王子病院におい て研究の趣旨をポスターにより広報することによつ て対象患者への認知を徹底した。

1-2. 対象薬剤 低用量アスピリン製剤とし て，バイアスピリン®錠 $100 \mathrm{mg}$ を対象薬剤とした。 NSAIDs 製剂は東海大八王子病院採用の 16 成分 17 品目の，アンフェナクナトリウム（フェナゾック ス ${ }^{\circledR}$ カプセル $50 \mathrm{mg}$ )，イブプロフェン（ブルフェ ン®錠 100)，インドメタシンファルネシル（インフ リーツカプセル $100 \mathrm{mg}$ )，エトドラク（ハイペン錠 $200 \mathrm{mg}$ )，ザルトプロフェン (ペオン錠 80), ジク ロフェナクナトリウム（ボルタレン®錠 $25 \mathrm{mg}$ ），ジ クロフェナクナトリウム徐放性製剤（ボルタレン® $\mathrm{SR}$ カプセル $37.5 \mathrm{mg}$ )，スリンダク（クリノリル ${ }^{\circledR}$ 錠 100)，セレコキシブ（セレコックス錠 100 $\mathrm{mg}$ ), チアプロフェン酸（スルガム錠 $200 \mathrm{mg}$ ), ナプロキセン（ナイキサン錠 $100 \mathrm{mg}$ ），ナブメト ン（レリフェン錠 $400 \mathrm{mg}$ ), メフェナム酸（ポン タールカカプセル $250 \mathrm{mg}$ ), メロキシカム（モービ ック錠 $10 \mathrm{mg}$ )，モフェゾラク（ジソペイン錠 75)，ロキソプロフェンナトリウム（ロキソニン®錠 $60 \mathrm{mg}$ ) 及びロルノキシカム（ロルカム錠 $4 \mathrm{mg}$ ) を対象薬剤とした。

1-3. 調査項目 消化管障害発現患者において 下記の項目について調査を行い，消化管障害の発現 状況を分析した。調査項目は対象薬剂の服用日数, 消化管障害の発現部位，対象薬剂の用法用量及び併 用薬とした。なお，バイアスピリン錠 $100 \mathrm{mg}$ を 服用していた患者をアスピリン服用群，NSAIDs を 服用していた患者を NSAIDs 服用群とした。情報 収集は個人情報保護法に配慮して行った。

1-4. 低用量アスピリンと NSAIDsによる消化管 障害の発現頻度の比較 アスピリン服用群と NSAIDs 服用群における消化管障害の発現頻度につ いて比較検討した。薬物治療の特性上，低用量アス ピリンを服用している患者では服用日数が長いた め，服用日数を 150 日以下，200日以下，250日以 下及び全服用期間に分けて，アスピリン服用群と NSAIDs 服用群における消化管障害の発現頻度を算 出した.

1-5. 統計 消化管障害の発現頻度の比較には $\chi^{2}$ 検定を，服用日数の比較には対応のない $t$ 検定を 用いた。有意水準は $p<0.05$ とした。解析には 
$\mathrm{JMP}^{\circledR} 8.02$ (SAS Institute Inc.) を用いた。

2. アスピリン及び NSAIDsによる消化管障害 の危険性の評価

2-1. 対象薬物対象薬物は同一の実験におい て，胃における $\mathrm{PGE}_{2}$ 産生に対する $\mathrm{IC}_{50}$ 值が報告 され, ${ }^{8)}$ かつ薬物動態学的パラメータが得られたア スピリン，イブプロフェン，インドメタシン，才キ サプロジン，ジクロフェナク徐放性製剤，ナプロキ セン，ピロキシカムとした，さらに，上記と同一の 実験ではないが，ヒトの胃細胞における $\mathrm{PGE}_{2}$ 産生 に対する $\mathrm{IC}_{70}$ 值の報告があるロキソプロフェンも 対象薬物とした。

2-2. 薬物動態学的パラメータ及び薬力学的パラ メー夕対象薬物の用法用量, 分子量, 最高血漿 中薬物濃度 $\left(\mathrm{C}_{\mathrm{pmax}}\right)$, 血漿中タンパク非結合型分率 $\left(\mathrm{f}_{\mathrm{u}}\right)$ に関するデータを文献より収集した. ${ }^{9-26)}$ ま た，薬力学的パラメータとして，各薬物の胃におけ る $\mathrm{PGE}_{2}$ 産生に対する $\mathrm{IC}_{50}$ 值を文献より収集し た。ロキソプロフェン以外の各薬物の $\mathrm{IC}_{50}$ 值は同 一実験にてヒトの胃生検によって得られた切片に各 薬物を 6 濃度添加することにより算出されたデー夕 を用いた。 ${ }^{8)} ロ$ ロソプロフェンにおいては，上記 データより $\mathrm{IC}_{50}$ 值が得られなかったため，ヒトの 胃細胞にロキソプロフェン及びその活性代謝物であ るロキソプロフェン - $\mathrm{OH}$ 体を 6 濃度添加すること により算出された $\mathrm{IC}_{70}$ 值を基に $\mathrm{IC}_{50}$ 值を算出し た. ${ }^{27)}$ ロキソプロフェン及びロキソプロフェン -OH 体の $\mathrm{IC}_{50}$ 值の算出は，上記の両論文に報告があつ たインドメタシンの $\mathrm{IC}_{50}$ 值及び $\mathrm{IC}_{70}$ 值を基準に用 い，下記に示す方法で行った。

ロキソプロフェン及びインドメタシンの $\mathrm{IC}_{70}$ 值 と $\mathrm{IC}_{50}$ 值の関係は，Eq. (1) 及び(2)で表現できる.

$$
\begin{aligned}
& 70=\frac{\mathrm{IC}_{70}^{\mathrm{L}}}{\mathrm{IC}_{50}^{\mathrm{L}}+\mathrm{IC}_{70}^{\mathrm{L}}} \cdot 100 \\
& 70=\frac{\mathrm{IC}_{70}^{\mathrm{I}}}{\mathrm{IC}_{50}^{\mathrm{I}}+\mathrm{IC}_{70}^{\mathrm{I}}} \cdot 100
\end{aligned}
$$

ここで, $\mathrm{IC}_{70}^{\mathrm{L}}, \mathrm{IC}_{50}^{\mathrm{L}}$ はロキソプロフェンの $\mathrm{IC}_{70}$, $\mathrm{IC}_{50}$ 值を, $\mathrm{IC}_{70}^{\mathrm{I}}, \mathrm{IC}_{50}^{\mathrm{I}}$ はインドメタシンの $\mathrm{IC}_{70}, \mathrm{IC}_{50}$ 值を示す。そして，Eq. (1)と Eq. (2)より，Eq. (3)の関係が得られる。

$$
\frac{\mathrm{IC}_{70}^{\mathrm{L}}}{\mathrm{IC}_{50}^{\mathrm{L}}}=\frac{\mathrm{IC}_{70}^{\mathrm{I}}}{\mathrm{IC}_{50}^{\mathrm{I}}}
$$

つまり, Eq. (4)の結果が得られる.

$$
\mathrm{IC}_{70}^{\mathrm{L}}: \mathrm{IC}_{70}^{\mathrm{I}}=\mathrm{IC}_{50}^{\mathrm{L}}: \mathrm{IC}_{50}^{\mathrm{I}}
$$

ここで， $\mathrm{IC}_{70}^{\mathrm{L}}$ と $\mathrm{IC}_{70}^{\mathrm{I}}$ に同一実験27)の值を代入し， $\mathrm{IC}_{50}^{\mathrm{I}}$ にロキソプロフェン以外の薬物の $\mathrm{IC}_{50}$ 值が求 められた実験8) におけるインドメタシンの $\mathrm{IC}_{50}^{\mathrm{I}}$ 值を 代入することにより，その実験8) 条件下で得られる ロキソプロフェンの $\mathrm{IC}_{50}$ 值を算出した。 また，同 様の方法にて，ロキソプロフェン - $\mathrm{OH}$ 体の $\mathrm{IC}_{50}$ 值 も算出した。

2-3. 見かけの胃 $\mathbf{P G E}_{2}$ 産生阻害率の算出 対 象薬物の血漿中非結合型薬物濃度 $\left(\mathrm{C}_{\mathrm{p}}^{\mathrm{f}}\right)$ 及び各薬 物の胃における $\mathrm{PGE}_{2}$ 産生阻害に関する $\mathrm{IC}_{50}$ 值を Eq.（5）に代入して，見かけの胃 $\mathrm{PGE}_{2}$ 産生阻害率 （I）を算出した.

$$
\mathrm{I}=\frac{\mathrm{C}_{\mathrm{p}}^{\mathrm{f}}}{\mathrm{IC}_{50}+\mathrm{C}_{\mathrm{p}}^{\mathrm{f}}} \cdot 100
$$

活性代謝物が存在するロキソプロフェンに関して は，未変化体と活性代謝物の競合阻害を加味した Eq. (6)により，I を算出した.

$$
\begin{aligned}
\mathrm{I}= & \frac{\mathrm{C}_{\mathrm{p}}^{\mathrm{f}, \mathrm{L}}}{\left\{\mathrm{IC}_{50}^{\mathrm{L}} \cdot\left(1+\frac{\mathrm{C}_{\mathrm{p}}^{\mathrm{f}, \mathrm{OH}}}{\mathrm{IC}_{50}^{\mathrm{OH}}}\right)+\mathrm{C}_{\mathrm{p}}^{\mathrm{f}, \mathrm{L}}\right\}} \cdot 100 \\
& +\frac{\mathrm{C}_{\mathrm{p}}^{\mathrm{f}, \mathrm{OH}}}{\left\{\mathrm{IC}_{50}^{\mathrm{OH}} \cdot\left(1+\frac{\mathrm{C}_{\mathrm{p}}^{\mathrm{f}, \mathrm{L}}}{\mathrm{IC}_{50}^{\mathrm{L}}}\right)+\mathrm{C}_{\mathrm{p}}^{\mathrm{f}}, \mathrm{OH}\right\}} \cdot 100
\end{aligned}
$$

ここで， $C_{\mathrm{p}}^{\mathrm{f}, \mathrm{L}}$ 及び $\mathrm{IC}_{50}^{\mathrm{L}}$ はロキソプロフェンの值, $\mathrm{C}_{\mathrm{P}}^{\mathrm{f}, \mathrm{OH}}$ 及び $\mathrm{IC}_{50}^{\mathrm{OH}}$ は活性代謝物の值を示している.

2-4. 胃 $\mathrm{PGE}_{2}$ 産生阻害率の実測値と算出値との 関係上記 2-3.の式より算出された I 值が，実 際にヒトにおいて薬物服用後の胃の $\mathrm{PGE}_{2}$ 産生阻害 率を反映しているかを確かめるため，胃生検片中の $\mathrm{PGE}_{2}$ 産生阻害率の実測值が得られた薬物を対象 に, 実測値と見かけの胃 $\mathrm{PGE}_{2}$ 産生阻害率の算出値 との関係について検討した。胃 $\mathrm{PGE}_{2}$ 産生阻害率の 実測値は，薬物服用前後に胃生検片中の $\mathrm{PGE}_{2}$ 量が 測定された報告值を用いた。見かけの胃 $\mathrm{PGE}_{2}$ 産生 阻害率の算出は，実測值を引用した報告における胃 生検施行時間を基に，その時点の血漿中非結合型薬 物濃度を血漿中薬物濃度推移のデータから算出し,

Eq. (5)に代入して求めた.

2-5. 日本人における各薬物投与後の見かけの胃 $\mathrm{PGE}_{2}$ 産生阻害率の比較 2-4. において実測值と 見かけの胃 $\mathrm{PGE}_{2}$ 産生阻害率の算出値との間に対応 が得られることを確認後, 対象薬物の最高血漿中非 
結合型薬物濃度 $\left(\mathrm{C}_{\mathrm{p} \text { max }}^{\mathrm{f}}\right)$ 及び $\mathrm{IC}_{50}$ 值を $\mathrm{Eq}$. (5) 又 は Eq. (6)に代入して，見かけの最大胃 $\mathrm{PGE}_{2}$ 産生 阻害率（ $\mathrm{I}_{\max }$ ) を算出し，アスピリンと NSAIDs と の比較を行った。なお，薬物動態学的パラメー夕に ついては，日本人におけるデー夕を用い，各薬物の 用量は 1 回常用量の中央值を用いた.

\section{結果}

1. 低用量アスピリンと NSAIDsによる消化管 障害の発現頻度の比較

1-1. NSAIDs による消化管障害の発現 NSAIDs 服用群は 1856 名（ロキソプロフェンナトリウム： 1355 名，セレコキシブ : 141 名，エトドラク : 158 名, メロキシカム : 98 名, ナプロキセン : 45 名, イブプロフェン：14 名，ジクロフェナクナトリウ ム徐放性製剂：45 名）であった。 NSAIDs 服用群 のうち 5 名において消化管障害が発現し，服用して いた NSAIDs の種類は 3 種類であった。その内訳 は，ロキソプロフェンナトリウムが 3 名，メロキシ カムが 1 名, ナプロキセンが 1 名であった。

NSAIDs による消化管障害の発現頻度は 0.27\%（5/ 1856）であった。なお，NSAIDs 服用群の平均年齢 は $59.1 \pm 16.7$ 歳，性別は男性 844 名，女性 1012 名 であった。

1-2. 低用量アスピリンによる消化管障害の発現 アスピリン服用群は 1103 名であった。アスピリ ン服用群のうち 28 名において消化管障害が発現 し，アスピリンによる消化管障害の発現頻度は 2.54\%（28/1103）であった。なお，アスピリン服 用群の平均年齢は $67.6 \pm 12.5$ 歳, 性別は男性 659 名，女性 444 名であった。

1-3. アスピリン服用群と NSAIDs 服用群の消化 管障害の発現頻度の比較アスピリン服用群と NSAIDs 服用群について消化管障害の発現頻度を比 較した。また，両群における消化管障害発現患者の 平均薬剂服用日数を比較した結果，アスピリン服用 群で 680.9 \pm 583.1 日， NSAIDs 服用群で $257.0 \pm$ 302.8 日であり，アスピリン服用群のほうが有意に 服用日数が長かった（Table 1)。そこで，両群の服 用期間を一定にして評価するために，服用期間毎に 消化管障害の発現頻度を比較検討した。アスピリン 服用群と NSAIDs 服用群について服用期間を 150 日以下，200 日以下及び 250 日以下に分けた場合と
Table 1. Incidence of Gastroduodenal Disorders with the Duration of Each Treatment in Patients Taking Aspirin or NSAIDs Alone

\begin{tabular}{|c|c|c|c|}
\hline $\begin{array}{l}\text { Treatment } \\
\text { duration }\end{array}$ & $\begin{array}{c}\text { Gastroduodenal } \\
\text { disorder }\end{array}$ & Aspirin & NSAID \\
\hline \multirow{3}{*}{$\sim 150$ days } & Disorder & $4(1.04 \%)^{*}$ & $3(0.19 \%)$ \\
\hline & No disorder & 380 & 1567 \\
\hline & $\begin{array}{l}\text { Average treat- } \\
\text { ment duration }\end{array}$ & $90.8 \pm 23.9$ & $109.3 \pm 12.0$ \\
\hline \multirow{3}{*}{$\sim 200$ days } & Disorder & $7(1.47 \%) *$ & $4(0.24 \%)$ \\
\hline & No disorder & 468 & 1668 \\
\hline & $\begin{array}{l}\text { Average treat- } \\
\text { ment duration }\end{array}$ & $124.6 \pm 45.8$ & $122.0 \pm 27.2$ \\
\hline \multirow{3}{*}{$\sim 250$ days } & Disorder & $10(1.82 \%) *$ & $4(0.23 \%)$ \\
\hline & No disorder & 539 & 1717 \\
\hline & $\begin{array}{l}\text { Average treat- } \\
\text { ment duration }\end{array}$ & $156.7 \pm 64.0$ & $122.0 \pm 27.2$ \\
\hline \multirow{3}{*}{$\begin{array}{l}\text { Entire study } \\
\text { period }\end{array}$} & Disorder & $28(2.54 \%) *$ & $5(0.27 \%)$ \\
\hline & No disorder & 1075 & 1851 \\
\hline & $\begin{array}{l}\text { Average treat- } \\
\text { ment duration }\end{array}$ & $680.9 \pm 583.1^{* *}$ & $257.0 \pm 302.8$ \\
\hline
\end{tabular}

${ }^{*} p<0.05$ as compared with NSAID, chi-squared test, ${ }^{* *} p<0.05$ as compared with NSAID, unpaired $t$-test.

全服用期間の消化管障害の発現頻度と消化管障害発 現患者の平均薬剂服用日数を Table 1 に示した。各 服用期間及び全服用期間ともに，アスピリン服用群 は NSAIDs 服用群よりも消化管障害の発現頻度が 有意に高值を示した。平均薬剤服用日数においては, 250 日以下までは両群に有意差はみられなかった。 よって，アスピリン服用群は NSAIDs 服用群に比 べて消化管障害の発現頻度が有意に高いことが示唆 された。

2. アスピリン及び NSAIDsによる消化管障害 の危険性の評価

2-1. 胃 $\mathbf{P G E}_{2}$ 産生阻害率の実測値と算出値との 関係 Table 2 に文献より得られた胃生検片中の $\mathrm{PGE}_{2}$ 産生阻害率の実測值を示した。実測值とし て，アスピリンは 1 回 $81 \mathrm{mg} 1$ 日 1 回 46 日間服用 2 時間後, ナプロキセンは 1 回 $500 \mathrm{mg} 1$ 日 2 回 28 日間服用後，イブプロフェンは 1 回 $400 \mathrm{mg} 1$ 日 3 回 10 日間服用 90 分後, ピロキシカムは 1 回 $20 \mathrm{mg}$ 1 日 1 回 7 日間服用後の胃 $\mathrm{PGE}_{2}$ 産生阻害率のデー タが得られた。なお、インドメタシンは 1 回 $50 \mathrm{mg}$ 1 日 3 回 28 日間服用 4-5 時間後の胃 $\mathrm{PGE}_{2}$ 産生阻 害率と, 1 回 $50 \mathrm{mg} 1$ 日 3 回 10 日間服用 8-10 時間 
Table 2. Actual Values for Inhibition of Gastric $\mathrm{PGE}_{2}$

\begin{tabular}{lcccccc}
\hline \hline \multicolumn{1}{c}{ Drug } & Dosage & $\begin{array}{c}\text { Usage } \\
\text { (per day) }\end{array}$ & $\begin{array}{c}\text { Duration of } \\
\text { administration } \\
\text { (days) }\end{array}$ & $\begin{array}{c}\text { Time after last } \\
\text { administration }\end{array}$ & $\begin{array}{c}\text { Actual } \\
\text { value }(\%)\end{array}$ & $\begin{array}{c}\text { Calculated } \\
\text { value }(\%)\end{array}$ \\
\hline Aspirin & $81 \mathrm{mg}$ & 1 & 46 & $2 \mathrm{~h}$ & $88.9^{9)}$ & 98.9 \\
Naproxen & $500 \mathrm{mg}$ & 2 & 28 & More than $4 \mathrm{~h}$ & $68.7^{10)}$ & 84.2 \\
Ibuprofen & $400 \mathrm{mg}$ & 3 & 10 & $90 \mathrm{~min}$ & $83.8^{11)}$ & 69.7 \\
Indometacin & $50 \mathrm{mg}$ & 3 & 28 & $4-5 \mathrm{~h}$ & $56.6^{12)}$ & 64.4 \\
Indometacin & $50 \mathrm{mg}$ & 3 & 10 & $8-10 \mathrm{~h}$ & $3.4^{13)}$ & 2.8 \\
Piroxicam & $20 \mathrm{mg}$ & 1 & 7 & - & $55.5^{14)}$ & 37.5 \\
\hline
\end{tabular}

-: not reported.

後の胃 $\mathrm{PGE}_{2}$ 産生阻害率の 2 つのデータが得られた ため，両データともに実測值として用いた。

胃 $\mathrm{PGE}_{2}$ 産生阻害率の算出値を Table 2 に, 実測 值と算出値との関係を Fig. 1 に示した。見かけの 胃 $\mathrm{PGE}_{2}$ 産生阻害率の算出値は，アスピリンが 98.9\%, ナプロキセンが $84.2 \%$ ，イブプロフェンが $69.7 \%$ ，インドメタシンを 1 回 $50 \mathrm{mg} 1$ 日 3 回 28 日間服用 4-5 時間後の值が $64.4 \% ， 1$ 回 $50 \mathrm{mg} 1$ 日 3 回 10 日間服用 8-10 時間後の值が $2.8 \%$, ピロキ シカムが $37.5 \%$ あっった。なお，アスピリンは COX-1 を非可逆的に阻害し，胃においてもその阻 害作用は長く持続する. アスピリン $81 \mathrm{mg}$ 服用 48 時間後までは高い胃 $\mathrm{PGE}_{2}$ 阻害作用が続くことが報

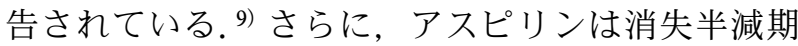
が $24.0 \pm 7.8$ 分 ${ }^{15)}$ と非常に短く, 最高血中濃度到達 時間 $\left(\mathrm{T}_{\max }\right)$ も $23.4 \pm 8.4$ 分 ${ }^{15)}$ と短時間である。そ のため，アスピリンの胃 $\mathrm{PGE}_{2}$ 阻害作用は，アスピ リン服用後から $\mathrm{T}_{\max }$ まではその時点における $\mathrm{C}_{\mathrm{p}}^{\mathrm{f}}$ に, $\mathrm{T}_{\max }$ から 48 時間までは $\mathrm{C}_{\mathrm{pmax}}^{\mathrm{f}}$ に依存すると仮定 し，アスピリンの見かけの胃 $\mathrm{PGE}_{2}$ 産生阻害率は $\mathrm{C}_{\mathrm{p} \text { max }}^{\mathrm{f}}$ を用いて算出した。 また，ピロキシカムにお いては，胃 $\mathrm{PGE}_{2}$ 産生阻害率の実測值の文献に 7 日 間服用後の胃生検時間が記載されていなかつた。し かし， 7 日間服用後 0-4 時間以内に血漿中薬物濃度 が測定されていたため，その時に生検が行われたと 仮定して，見かけの胃 $\mathrm{PGE}_{2}$ 産生阻害率を算出した.

胃 $\mathrm{PGE}_{2}$ 産生阻害率の実測値と見かけの胃 $\mathrm{PGE}_{2}$ 産生阻害率の算出値との間には， $\mathrm{y}=0.958 \mathrm{x} ，$ 相関 係数 0.902 の有意な関係が得られた $(p<0.0001)$. したがって，理論的に算出した各薬物投与後の見か けの胃 $\mathrm{PGE}_{2}$ 産生阻害率が実測值を反映することが 示唆された。

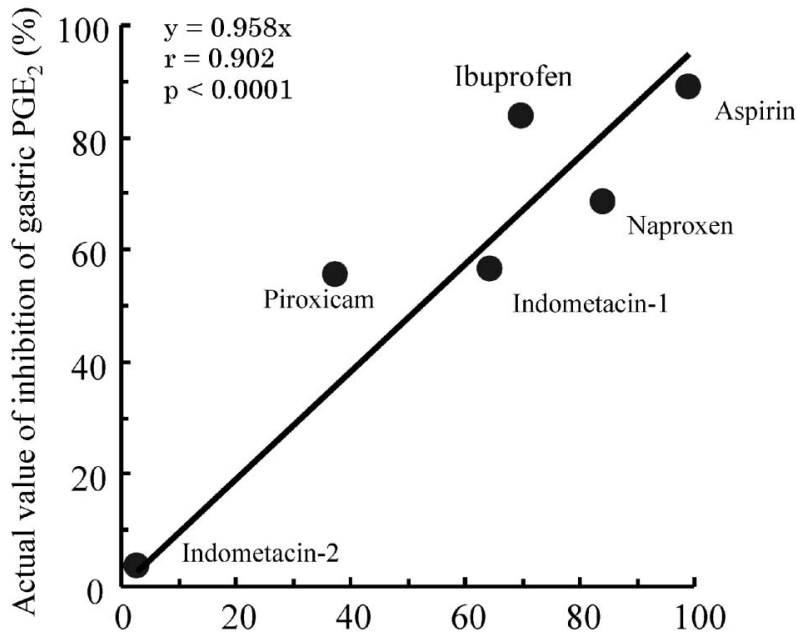

Calculated value of inhibition of gastric $\mathrm{PGE}_{2}(\%)$

Fig. 1. Relationship between Actual and Calculated Values for Inhibition of Gastric $\mathrm{PGE}_{2}$

Treatment condition; aspirin, $2 \mathrm{~h}$ after administration $81 \mathrm{mg}$ once daily for 46 days; naproxen, $4 \mathrm{~h}$ or more after administration $500 \mathrm{mg}$ twice daily for 28 days; ibuprofen, $90 \mathrm{~min}$ after administration $400 \mathrm{mg} 3$ times daily for 10 days; Indometacin-1, $4-5 \mathrm{~h}$ after administration $50 \mathrm{mg} 3$ times daily for 28 days; Indometacin-2, 8-10 h after administration $50 \mathrm{mg} 3$ times daily for 10 days; Piroxicam, $0-4 \mathrm{~h}$ after administration $20 \mathrm{mg}$ once daily for 7 days.

\section{2-2. 日本人における各薬物投与後の見かけの胃} $\mathbf{P G E}_{2}$ 産生阻害率の比較２-1. において，実測値 と見かけの胃 $\mathrm{PGE}_{2}$ 産生阻害率の算出值の間に良好 な関係があることが見い出されたため, アスピリン 及びNSAIDsを常用量の中央値の用量で投与した 時の $\mathrm{C}_{\mathrm{pmax}}^{\mathrm{f}}$ を用いて, 見かけの最大胃 $\mathrm{PGE}_{2}$ 産生阻 害率 $\left(\mathrm{I}_{\max }\right)$ を算出した。算出する際に用いた薬物 動態学的パラメータ及び薬力学的パラメータと，算 出した見かけの最大胃 $\mathrm{PGE}_{2}$ 産生阻害率を Table 3 に示した.さらに，各薬物の算出した見かけの最大 胃 $\mathrm{PGE}_{2}$ 産生阻害率を Fig. 2 に示した。なお，ロキ ソプロフェンの $\mathrm{IC}_{50}$ 值は, インドメタシンの $\mathrm{IC}_{70}$ 
Table 3. Pharmacokinetic Parameters, Pharmacodynamic Parameters and Calculated Maximum Inhibition of Gastric PGE 2 after Administration of Usual Doses of Aspirin or NSAIDs

\begin{tabular}{|c|c|c|c|c|c|c|c|}
\hline Drug & $\begin{array}{c}\text { Median } \\
\text { standard dose }\end{array}$ & M.W. & $\begin{array}{l}\mathrm{C}_{\mathrm{p}_{\max }} \pm \mathrm{S} . \mathrm{D} . \\
(\mu \mathrm{M})\end{array}$ & $\mathrm{f}_{\mathrm{u}}$ & $\begin{array}{l}\mathrm{C}_{\mathrm{p}_{\max }}^{\mathrm{f}} \pm \mathrm{S} . \mathrm{D} . \\
(\mu \mathrm{M})\end{array}$ & $\begin{array}{c}\text { Gastric } \\
\mathrm{IC}_{50}(\mu \mathrm{M})\end{array}$ & $\begin{array}{c}\mathrm{I}_{\max }(\%) \\
(- \text { S.D. } \sim+\text { S.D. })\end{array}$ \\
\hline Aspirin ${ }^{15,16)}$ & $\begin{array}{c}81 \mathrm{mg}, \\
\text { once a day }\end{array}$ & 180.16 & $6.58 \pm 1.68$ & 0.417 & $2.74 \pm 0.70$ & 0.03 & $\begin{array}{c}98.9 \\
(-0.37 \sim+0.22)\end{array}$ \\
\hline Naproxen ${ }^{17,18)}$ & $\begin{array}{l}200 \mathrm{mg}, \\
\text { twice a day }\end{array}$ & 230.26 & 126.2 & 0.01 & 1.26 & 0.52 & 70.8 \\
\hline Ibuprofen ${ }^{19)}$ & $\begin{array}{c}200 \mathrm{mg}, \\
3 \text { times a day }\end{array}$ & 206.28 & $80.47 \pm 4.36$ & 0.01 & $0.80 \pm 0.04$ & 0.70 & $\begin{array}{c}53.5 \\
(-1.39 \sim+1.31)\end{array}$ \\
\hline Indometacin 20,21$)$ & $\begin{array}{c}25 \mathrm{mg} \\
3 \text { times a day }\end{array}$ & 357.79 & $7.69 \pm 1.31$ & 0.10 & $0.77 \pm 0.13$ & 0.85 & $\begin{array}{c}47.5 \\
(-4.64 \sim+3.94)\end{array}$ \\
\hline Oxaprozin ${ }^{22)}$ & $\begin{array}{c}400 \mathrm{mg}, \\
\text { once a day }\end{array}$ & 293.32 & $225.35 \pm 8.52$ & 0.0025 & $0.56 \pm 0.02$ & 2.62 & $\begin{array}{c}17.7 \\
(-0.55 \sim+0.55)\end{array}$ \\
\hline Diclofenac 23,24$)$ & $\begin{array}{l}37.5 \mathrm{mg}, \\
\text { twice a day }\end{array}$ & 295.13 & $1.48 \pm 0.39$ & 0.01 & $0.01 \pm 0.0039$ & 0.23 & $\begin{array}{c}6.0 \\
(-1.54 \sim+1.49)\end{array}$ \\
\hline Piroxicam ${ }^{25)}$ & $\begin{array}{c}20 \mathrm{mg}, \\
\text { once a day }\end{array}$ & 331.35 & $6.28 \pm 0.15$ & 0.008 & $0.05 \pm 0.0012$ & 0.87 & $(-0.12 \sim+0.12)$ \\
\hline Loxoprofen ${ }^{26,27)}$ & \multirow{2}{*}{$\begin{array}{c}60 \mathrm{mg} \\
3 \text { times a day }\end{array}$} & 245.32 & $20.55 \pm 1.10$ & 0.03 & $0.62 \pm 0.03$ & 25.08 & \multirow{2}{*}{$\begin{array}{c}3.67 \\
(-0.15 \sim+0.15)\end{array}$} \\
\hline Loxoprofen-OH ${ }^{26,27)}$ & & 248 & $3.43 \pm 0.08$ & 0.072 & $0.25 \pm 0.01$ & 9.14 & \\
\hline
\end{tabular}

M.W.: molecular weight, $\mathrm{I}_{\max }$ : maximum inhibition of gastric $\mathrm{PGE}_{2}$.

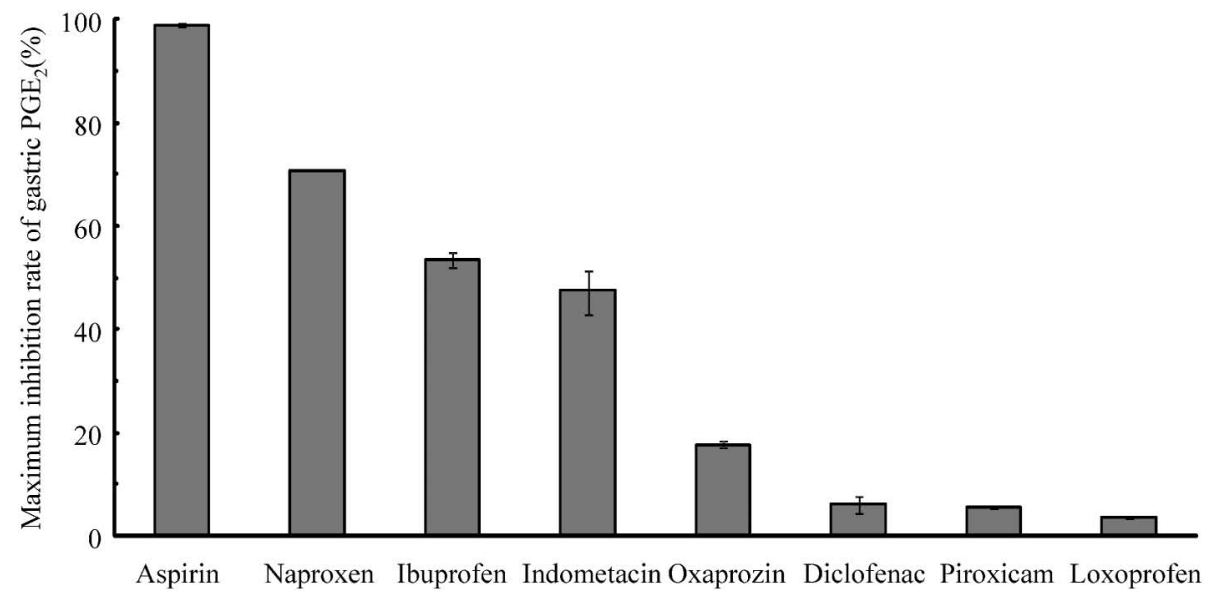

Fig. 2. Maximum Inhibition of Gastric $\mathrm{PGE}_{2}$ after Administration of Usual Dose of Aspirin and NSAIDs

值 $0.40 \mathrm{mM},{ }^{27)}$ ロキソプロフェンの $\mathrm{IC}_{70}$ 值 11.8 $\mathrm{mM}^{27)}$ 及びインドメタシンの $\mathrm{IC}_{50}$ 值 $0.85 \mu \mathrm{M}^{8)}$ を用 いて算出した結果， $25.08 \mu \mathrm{M}$ であった。同様にロ キソプロフェン- $\mathrm{OH}$ 体の $\mathrm{IC}_{50}$ 值は，インドメタシ ンの $\mathrm{IC}_{70}$ 值 $0.40 \mathrm{~mm},{ }^{27)}$ ロキソプロフェン-OH 体 の $\mathrm{IC}_{70}$ 值 $4.3 \mathrm{mM}^{27)}$ 及びインドメタシンの $\mathrm{IC}_{50}$ 值 $0.85 \mu \mathrm{M}^{8)}$ を用いて算出した結果，9.14 $\mu \mathrm{M}$ であった.

見かけの最大胃 $\mathrm{PGE}_{2}$ 産生阻害率はアスピリンが 98.9\%と最も高く，ついでナプロキセンが $70.8 \%$, イブプロフェンが $53.5 \%$ ，インドメタシンが 47.5 \%, オキサプロジンが $17.7 \%$ ，ジクロフェナクが
6.0\%，ピロキシカムが $5.5 \%$ ， ロキソプロフェンが $3.67 \%$ の順であった.

$$
\text { 考察 }
$$

低用量アスピリンによる消化管障害の誘発性を明 らかにするために，まずアスピリン服用群と NSAIDs 服用群における，消化管障害の発現頻度に ついて検討した。本研究の対象患者群に関して，ア スピリン服用群と NSAIDs 服用群の間に, 平均年 齢で有意差（ $p<0.05$ ，対応のない $t$ 検定）があっ たものの，アスピリン服用群では $67.6 \pm 12.5$ 歳, 
NSAIDs 服用群では $59.1 \pm 16.7$ 歳であり, 両群と もに平均年齢 50 歳以上であった。胃潰瘍の罹患率 は，55-64 歳でピークに達し，65 歳以上では減少傾 向にあると報告されている. ${ }^{28)} よ っ て ，$ 本研究の対 象患者群が，消化管障害の自然発生率に大きな影響 は与えないと考えられた。また，本研究は遡及的調 査研究であり，NSAIDs の種類において，服用患者 数（母数）に偏りが生じたため, COX-1 に対する 作用様式の違い，つまり，非可逆的阻害作用を示す アスピリンと，可逆的阻害作用を示すアスピリン以 外の NSAIDs に分類して消化管障害の発現頻度を 比較した.

消化管障害の発現頻度を調査した結果，アスピリ ン服用群における消化管障害の発現頻度は $2.54 \%$ (28/1103)，NSAIDs 服用群は 0.27\%（5/1856）で あり，アスピリン服用群のほうが消化管障害の発現 頻度は有意に高值を示した（ $p<0.05 ， \chi^{2}$ 検定).

NSAIDs 服用群において，消化管障害の危険性の評 価の検討で同一実験での $\mathrm{IC}_{50}$ 值の報告が得られな かつたため対象外となつたメロキシカムで消化管障 害が 1 名発現した。本研究におけるメロキシカムの 消化管障害発現頻度は $1.02 \%(1 / 98)$ であり，国内 承認時までの臨床試験及び製造販売後調査の胃炎の 発現率は $0.3 \%(18 / 6693)$ ，上腹部痛 $1.1 \%(72 /$ 6693）であり, 29) 発現頻度としては同様の結果であ ったことが示唆される.

一方，アスピリン服用群と NSAIDs 服用群の消 化管障害発現患者の平均薬剂服用日数を比較したと ころ，アスピリン服用群のほうが有意に長かった。 そこで，服用期間を一定にした時の消化管障害の発 現頻度について比較したところ，消化管障害発現患 者の平均薬剂服用日数に差がみられなかった 250 日 以下においても，消化管障害の発現頻度はアスピリ ン服用群が $1.82 \%$, NSAIDs 服用群が $0.23 \%$ と有 意に高值を示した $\left(p<0.05, \chi^{2}\right.$ 検定). 以上より， 低用量アスピリンは NSAIDs よりも消化管障害の 誘発性が高いことが示唆された。

本検討の結果では，低用量アスピリンによる消化 管障害の発現頻度は $2.54 \%$ であり，アスピリンを 75-325 mg/day の用量で 28 日間以上服用していた 患者において，消化性潰瘍が $10.7 \%$ ，びらん性病 変が $63.1 \%$ 発現したという海外の既報告6) 及び，バ イアスピリン錠 $100 \mathrm{mg}$ を約 6 年間服用していた

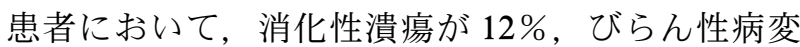
が $41 \%$ 発現したという国内の既報告4) と比較して低 値を示した。これは本調査が遡及的調査であり，上 部消化管内視鏡検查の施行が胃痛などの自覚症状を 訴えた患者に限定していたのに対し，既報告では自 覚症状のない患者についても上部消化管内視鏡検査 を施行していたことによるものと考えられた。ささ に，低用量アスピリンによる消化管障害は自覚症状 がそしいことが報告4,5)されているため，全例上部 消化管内視鏡検查を施行していた既報告よりも，消 化管障害の発現頻度が低值を示したと考えられた。

次に，アスピリン及び NSAIDs による消化管障 害の危険性の相違について，胃 $\mathrm{PGE}_{2}$ 産生阻害率を 基に理論的評価を行った．現在，NSAIDsによる胃

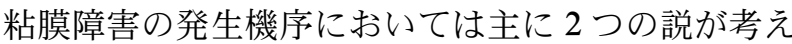
られている１つは本研究で取り上げた NSAIDs が PG 合成酵素である COX を阻害することにより， 胃粘膜の内因性 PG が減少し粘膜細胞保護作用が低 下するとともに，胃粘膜内微小循環障害をもきたし て粘膜障害が発生するという機序である。他の 1 つ は，NSAIDs による胃粘膜局所の直接障害であり， 酸性 NSAIDs は胃腔内 $\mathrm{pH}$ が酸性条件下で非イオ ン化した脂溶性となり，脂溶性の胃粘膜に取り込ま れる，胃粘膜は中性に近いため，細胞内の NSAIDs はイオン化に傾き $\mathrm{H}^{+}$を放出し，胃粘膜が障害され る機序である。

ただし，低用量アスピリン（325 mg 以下）にお いては，Kelly らの報告によると，素錠，制酸緩衝 錠及び腸溶錠の消化管障害の相対リスクが各 2.6 , 3.1 及び 2.7 であり，胃と十二指腸の出血に関する 相対リスクも各 $2.4 ， 2.6$ 及び 2.6 であり，剂形間 で有意差が認められなかった. ${ }^{30)}$ したがって，胃粘 膜における直接作用よりは COX を介した機序の方 が消化管障害への寄与が大きいと考えられた。

アスピリンは血中消失半減期が 0.4 時間と非常に 短いにもかかわらず，1 回 $81 \mathrm{mg}$ を 1 日 1 回 46 日 間服用 2 時間後の胃 $\mathrm{PGE}_{2}$ 産生阻害率は $88.9 \%$ で あり，投与終了後から 48 時間後までは胃 $\mathrm{PGE}_{2}$ 産 生阻害率がプラセボ投与群に比較して有意に低值を 示すことが報告されている. ${ }^{21)}$ 一方，インドメタシ ンを 1 回 $50 \mathrm{mg} 1$ 日 3 回 28 日間服用 4-5 時間後の 胃 $\mathrm{PGE}_{2}$ 産生阻害率が $56.6 \%,{ }^{12)} 1$ 回 $50 \mathrm{mg} 1$ 日 3 回 10 日間服用 8-10 時間後の胃 $\mathrm{PGE}_{2}$ 産生阻害率が 
$3.4 \%$ という報告がある. ${ }^{13)}$ インドメタシンの血中 消失半減期は約 1.7 時間であり, 服用後 8-10 時間 後では薬物はほぼ体内より消失している。つまり, アスピリンは COX-1 を非可逆的に阻害するため, $\mathrm{PGE}_{2}$ の機能回復に時間を要するが，インドメタシ ンのような NSAIDs は可逆的に阻害するため，胃 $\mathrm{PGE}_{2}$ 産生阻害率は血漿中薬物濃度に依存し, $\mathrm{PGE}_{2}$ の機能回復が速いと考えられた。そこで, NSAIDs はCOX-1を可逆的に阻害するために $\mathrm{PGE}_{2}$ の機能回復が速いのに対し，アスピリンは非 可逆的に阻害することにより $\mathrm{PGE}_{2}$ の機能回復が遅 いため，アスピリンによる消化管障害の発現頻度が NSAIDs と比べて高值を示すという作業仮説を構築 した，ただし，本研究では日本人における，対象薬 物投与前後の胃の $\mathrm{PGE}_{2}$ 産生阻害率の報告がなかっ たため，外国人の胃生検片中の $\mathrm{PGE}_{2}$ 産生阻害率を 用いた．胃の $\mathrm{PGE}_{2}$ 産生能の人種差に関する報告は なかったが，種々の酵素や受容体に対する $\mathrm{K}_{\mathrm{i}}$ 值に おいては，種差が少ないことをわれわれは報告して いるため, 31-33) 人種間で大きな違いはないものとし て検討した。ただし，日本人と外国人の胃 $\mathrm{PGE}_{2}$ 産 生能の同等性は明らかではないため絶対的な評価は 難しいが，本手法においてアスピリン及び NSAIDs における消化管障害の危険性についての相対的評価 は可能であると考えている。

そこで，文献より得られた胃 $\mathrm{PGE}_{2}$ 産生阻害率の 実測值と, 薬物動態学的パラメータ及び $\mathrm{IC}_{50}$ 值を 用いて算出した見かけの胃 $\mathrm{PGE}_{2}$ 産生阻害率の算出 值との関係を検討した結果，両者の間に $\mathrm{y}=$ $0.958 \mathrm{x}$ ，相関係数 0.902 の有意な相関関係が得られ た。ただし， $\mathrm{x}$ の係数が 0.958 と 1 より小さく，見 かけの胃 $\mathrm{PGE}_{2}$ 産生阻害率の算出值は実測值と比較 して若干高い值が算出された。これは，本検討では 解離定数 $\left(\mathrm{K}_{\mathrm{i}}\right)$ が得られなかつたため, $\mathrm{IC}_{50}$ 值 ${ }^{8)}$ を 用いて見かけの $\mathrm{PGE}_{2}$ 産生阻害率を算出したことに よると考えられる。しかし，両者の間に有意な関係 が得られたことから，同一実験条件下における $\mathrm{IC}_{50}$ 值を用いて見かけの胃 $\mathrm{PGE}_{2}$ 産生阻害率を算出 することにより，薬物間の胃 $\mathrm{PGE}_{2}$ 産生阻害率の程 度を相対的に比較することは可能であることが示唆 された。

薬物投与後の胃 $\mathrm{PGE}_{2}$ 産生阻害率の実測值と算出 值との間に関連性が示されたため，日本人にアスピ
リン及び NSAIDsを常用量の中央値の用量にて投 与した後の見かけの最大胃 $\mathrm{PGE}_{2}$ 産生阻害率を算出 して，相対的な比較を行った。見かけの最大胃 $\mathrm{PGE}_{2}$ 産生阻害率を算出した結果，アスピリンが 98.9\%と最も高值を示し，続いて，ナプロキセンが 70.8\%，イブプロフェンが $53.5 \%$ ，インドメタシン が $47.5 \%$ ，才キサプロジンが $17.7 \%$ ，ジクロフェ ナクが $6.0 \%$ ，ピロキシカムが $5.5 \%$ ，ロキソプロ フェンが $3.67 \%$ であた。本研究において，ナプ ロキセンの消化管障害発現頻度は $2.22 \%(1 / 45)$ と 高いものの，アスピリンの $2.54 \%(28 / 1103)$ より 低かった。同様に，ナプロキセンの見かけの最大胃 $\mathrm{PGE}_{2}$ 産生阻害率は $70.8 \%$ と高いものの，アスピリ ンの $98.9 \%$ よ低く, 消化管障害発現頻度と最大 胃 $\mathrm{PGE}_{2}$ 産生阻害率は対応していた。これは，ナプ ロキセンは消化管障害誘発性が高く，アスピリンと ナプロキセンの消化管障害発現に関する前向き無作 為化比較試験において，ナプロキセンはアスピリン と同程度の胃十二指腸粘膜障害を発現するという報 告を支持するものと考えられた。 ${ }^{34)}$ また，ロキソプ ロフェンの消化管障害発現率は $0.22 \%(3 / 1355)$ と 低值であり，見かけの最大胃 $\mathrm{PGE}_{2}$ 産生阻害率も $3.67 \%$ と低值を示し，両者の結果は対応していた。

これらの解析により，見かけの最大胃 $\mathrm{PGE}_{2}$ 産生 阻害率はアスピリンが $90 \%$ 以上と最も高い阻害率 を示すことが明らかとなり，さらにアスピリンは COX-1 を非可逆的に阻害するため, 高い $\mathrm{PGE}_{2}$ 産 生阻害率が長時間持続すると考えられた。つまり， 低用量アスピリンは，NSAIDs よりも，消化管障害 の誘発性が高いという根拠を理論的に示すことがで きたと考えられる。

本研究において，アスピリンは低用量においても 消化管障害誘発性が非常に高いことを，NSAIDs と の比較調査及び酵素阻害に基づいた理論的解析によ り示すことができた。この結果は，臨床において低 用量アスピリンによる消化管障害に十分な注意が必 要であることを示す根拠として，さらなる注意喚起 に有用なものであると考えられる。 また，われわれ は先の報告 ${ }^{35)}$ において，アスピリンによる消化管障 害は酸分泌抑制薬の併用の有無にかかわらず，アス ピリン投与後，早期に消化管障害が好発することを 示唆しており，特に投与早期の消化管障害について 注意深い観察を行うべきと考える. 


\section{REFERENCES}

1) Sakamoto C., Sugano K., Ota S., Sakaki N., Takahashi S., Yoshida Y., Tsukui T., Osawa H., Sakurai Y., Yoshino J., Mizokami Y., Mine T., Arakawa T., Kuwayama H., Saigenji K., Yakabi K., Chiba T., Shimosegawa T., Sheehan J. E., Perez-Gutthann S., Yamaguchi T., Kaufman D. W., Sato T., Kubota K., Terano A., Eur. J. Clin. Pharmacol., 62, 765772 (2006).

2) Cryer B., Goldschmiedt M., Redfern J. S., Feldman M., Gastroenterology, 99, 1616-1621 (1990)

3) Seibert K., Zhang Y., Leahy K., Hauser S., Masferrer J., Isakson P., Adv. Exp. Med. Biol., 400A, 167-170 (1997).

4) Yajima K., Hodozuka M., Takahashi K., Tomigahara Y., Akashi T., Kawai T., Yamashina A., Kizu J., J. Pharm. Health Care Sci., 35, 649-654 (2009) .

5) Abe S., Chiba T., Saito A., Abe H., Hamada S., Prog. Med., 28, 1995-2000 (2008).

6) Yeomans N. D., Lanas A. I., Talley N. J., Thomson A. B., Daneshjoo R., Eriksson B., Appelman-Eszczuk S., Langstrom G., Naesdal J., Serrano P., Singh M., Skelly M. M., Hawkey C. J., Aliment. Pharmacol. Ther., 22, 795-801 (2005).

7) Rostom A., Dube C., Wells G., Tugwell P., Welch V., Jolicoeur E., McGowan J., Cochrane Database Syst. Rev., 4, 1-60 (2002).

8) Cryer B., Feldman M., Am. J. Med., 104, 413 -421 (1998).

9) Feldman M., Shewmake K., Cryer B., Am. J. Physiol. Gastrointest. Liver Physiol., 279, G1113-G1120 (2000) .

10) Lipscomb G. R., Rees W. D., Aliment. Pharmacol. Ther., 10, 133-138 (1996).

11) Donnelly M. T., Richardson P., Hawkey C. J., Courtauld E., Stack W. A., Aliment. Pharmacol. Ther., 14, 543-549 (2000).

12) Shorrock C. J., Rees W. D., Gut, 33, 164-169 (1992)

13) Rademaker J. W., Rainsford K. D., Stetsko P. I., Johnson D. M., Chiba N., McDonald T. M., Hunt R. H., Aliment. Pharmacol. Ther.,
9, 625-631 (1995).

14) Rainsford K. D., James C., Johnson D. M., Stetsko P. I., Hill R. E., Salena B. J., Hunt R. H., Agents Actions, 39, C21-C23 (1993).

15) Interview form of Bufferin $81 \mathrm{mg}$ tablets, 2008.

16) Ghahramani P., Rowland-Yeo K., Yeo W. W., Jackson P. R., Ramsay L. E., Clin. Pharmacol. Ther., 63, 285-295 (1998).

17) Takahashi T., Sato Y., Radioisotopes, 22, 351 -359 (1973).

18) Nakayama Y., Morikawa I., Inoue T., Kurono M., Jpn. Pharmacol. Ther., 11, 4683-4686 (1983).

19) Interview form of Brufen tablets, 2010.

20) Interview form of indometacin $25 \mathrm{mg}$ capsules “isei”, 2009.

21) Komiyama T., Fukumoto M., Kubo H., Moriguchi I., Suguro N., J. Hosp. Pharm., 8, 259-267 (1982).

22) Azuma T., Watanabe T., Jpn. J. Clin. Pharmacol. Ther., 15, 555-565 (1984).

23) Tsunoo M., Yoshimura K., Maruyama Y., Takahashi M., Oikawa T., Iwasa A., Kuraishi T., Nishimura T., Inoue M., Kokita T., Numata H., Prog. Med., 9, 877-892 (1989) .

24) Thomson Reuters, Inc. Web. "PDR ${ }^{\circledR}$ Electronic Library.": 〈http://www.thomsonhc. com/home/dispatch $\rangle$, cited 28 April, 2011.

25) Interview form of Baxo capsules, 2008.

26) Interview form of Loxonin tablets, 2009.

27) Yamakawa N., Suemasu S., Kimoto A., Arai Y., Ishihara T., Yokomizo K., Okamoto Y., Otsuka M., Tanaka K., Mizushima T., Biol. Pharm. Bull., 33 398-403 (2010).

28) "EBM ni motozuku Ikaiyo Shinryo Guideline," ed. by the Study Group for the Formulation of a Gastric Ulcer Practice Guideline, Jiho, Inc., Tokyo, 2003, pp. 3-4.

29) Package Insert of Mobic tablets, 2010.

30) Kelly J. P., Kaufman D. W., Jurgelon J. M., Sheehan J., Koff R. S., Shapiro S., Lancet, 348, 1413-1416 (1996).

31) Yamada Y., Ito K., Nakamura K., Sawada Y., Iga T., Biol. Pharm. Bull., 16, 1251-1259 (1993)

32) Sawada Y., Yamada Y., Iga T., Yakugaku Zasshi, 117, 65-90 (1997).

33) Takayanagi R., Mizushima H., Ozeki T., 
Yokoyama H., Iga T., Yamada Y., Biol. Pharm. Bull., 30, 1297-1300 (2007).

34) Mehta S., Dasarathy S., Tandon R. K., Mathur M., Malaviya A. N., Am. J. Gastroenterol., 87, 996-1000 (1992).
35) Nakamura H., Yokoyama H., Yaguchi T., Suzuki Y., Tokuoka K., Watanabe M., Kitagawa Y., Yamada Y., Yakugaku Zasshi, 131, 445-452 (2011). 